\title{
БАГАТОВИМІРНА ГЕОМЕТРИЧНА МОДЕЛЬ ФУНКЦІОНУВАННЯ ТРАНСПОРТНОГО ПОТОКУ НА ПЕРЕВАНТАЖЕНІЙ ДІЛЯНЦІ ДОРОЖНЬОЇ МЕРЕЖІ
}

\footnotetext{
У роботі запропоновані ефективна методика збору вихідних даних, способи обробки та алгоритми розрахунку експлуатаційних параметрів транспортного потоку для удосконалення руху ТЗ із оптимальними показниками інтенсивності та швидкості на перевантажених ділянках дорожньої мережі. Проведена комп'ютерна реалізація запропонованих алгоритмів в середовищі Mathcad. Розроблена геометрична модель багатовимірного представлення залежностей між основними базовими характеристиками транспортного потоку у різні часові інтервали, яка дозволяє ефективно розріджувати щільність руху транспортних засобів у пікові періоди. Запропонована багатовимірна інтерпретація основної діаграми транспортного потоку, яка дає можливість швидко і якісно аналізувати стан пропускної здатності ТЗ на окремих ділянках дороги і ефективно приймати управлінські рішення щодо удосконалення трафіку.

Ключові слова: інтенсивність транспортного потоку, транспортний засіб, основна діаграма ТП, щільність руху ТЗ, багатовимірне представлення діаграми ТП.
}

Постановка проблеми. Оптимізація руху транспорту у будь-якому місті із розвинутою інфраструктурою залишається однією із головних урбаністичних проблем, а для іiї вирішення все більше значення відіграють методи математичного моделювання. Математичні моделі, що застосовуються сьогодні для опису та аналізу руху транспортних потоків по транспортній мережі міста доволі різноманітні, однак вони нерідко вносять у процес моделювання ряд неточностей принципового характеру $[9,10]$.

Транспортну мережу міста можна інтерпретувати як сукупність транспортних зв'язків, по яких здійснюються пасажирські або вантажні перевезення. Слід зауважити, що транспортна мережа, будьякого міста ніколи не відповідає дорожній мережі. Залежно від габаритів і маси вантажу, параметрів використовуваних транспортних засобів, транспортна мережа буде тільки тим чи іншим фрагментом дорожньої мережі $[1,3]$. Наприклад, не по усіх вулицях міста дозволений рух вантажних автомобілів, не на всіх вулицях облаштовані лінії для руху пасажирського електротранспорту і тому в транспортній мережі - ці вулиці для них будуть виключені.

Практично у кожному місті існують ділянки транспортної мережі типу «пляшкових горловин» із поганою організацією руху транспортних засобів (рис. 1), незадовільною пропускною здатністю у пікові години i, звідси, із підвищеною небезпекою до утворення заторів та аварійних ситуацій. Одним із ключових моментів для розуміння суті транспортного процесу на таких ділянках є науковообгрунтований, ефективний аналіз вихідних емпіричних даних та побудова на їх основі математичних моделей для удосконалення функціонування транспортних систем.

Аналіз останніх досліджень. Математичний

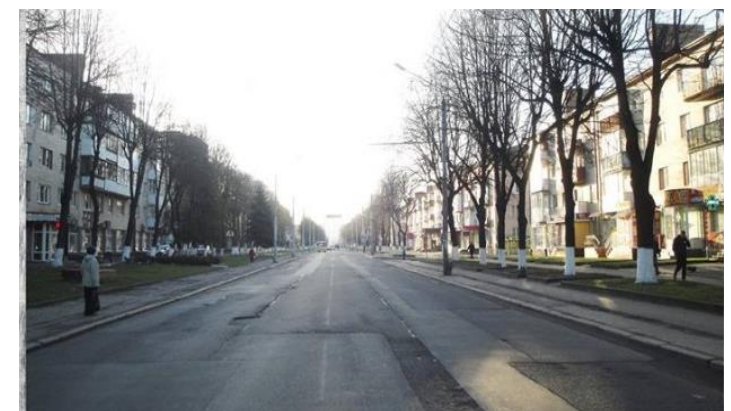

Рисунок 1 - Фрагмент ділянки транспортної мережі типу «пляшкова горловина» у м. Луцьку

опис транспортних потоків і пов'язаних із ними явищ, давно привертає увагу науковців, проте і на сьогодні не існує універсального математичного підходу до адекватного моделювання складних процесів, що спостерігаються у цій системі [2,4,5,20,21].

Більшість відомих моделей динаміки транспортних потоків можутьь бути умовно розділені на три групи:

$$
\begin{aligned}
& \text { макроскопічні; } \\
& \text { мікроскопічні; } \\
& \text { мезоскопічні моделі. }
\end{aligned}
$$

Макроскопічні моделі описують рух транспортних засобів в усереднених показниках $\mathrm{i}$ термінах, таких як щільність, середня швидкість, інтенсивність транспортного потоку та ін. [6]. 
Мікроскопічні моделі - у яких детально моделюється рух кожного транспортного засобу за допомогою звичайних диференціальних рівнянь. Такий підхід дозволяє теоретично досягти точнішого опису руху транспорту у порівнянні із макроскопічним моделюванням, проте у разі практичного застосування цей підхід вимагає від науковців величезних затрат часу та обчислювальних ресурсів. Особливе місце у групі мікро- моделей займають моделі типу «кліткових автоматів», що отримали широкий розвиток останніми роками. У них прийнятий надзвичайно спрощений дискретний у часі та просторі опис руху транспортних засобів, за рахунок чого досягається висока обчислювальна ефективність моделей даного виду [7].

Мезоскопічні моделі є проміжною ланкою між двома попередніми моделями. У них потік описується щільністю розподілу автомобілів у просторі координат і швидкостей ТЗ. Динаміка змін щільності описується кінетичними рівняннями, які грунтуються на усередненому описі взаємодії окремих автомобілів. Важливе теоретичне значення мезоскопічних моделей полягає в тому, що на їх основі можна, у заданому часовому інтервалі, застосовувати макроскопічні моделі [6].

Однією із перших математичних моделей автотранспортних потоків є макроскопічна LWмодель [7]. В даній моделі покладена однозначна залежність середньої швидкості потоку транспортних засобів від щільності автомобілів. Дана залежність дозволяє ввести такий показник як інтенсивність потоку (число автомобілів, що перетинають переріз автомагістралі у певній точці за одиницю часу). Відтак, між швидкістю руху, щільністю і інтенсивністю існує співвідношення, яке називається фундаментальним виразом для транспортного потоку.

$$
N=V \cdot Q
$$

де: $N$ - інтенсивність ТП;

$V$ - швидкість ТП;

$Q$ - щільність ТП.

Усі три величини у цьому виразі знаходяться у складній взаємозалежності, тому не можна аналізувати вираз, фіксуючи одну із них і довільно змінюючи значення іншої. Наприклад, підвищення швидкості руху знижує щільність потоку ТЗ на ділянці, через що інтенсивність руху може або зростати, або залишатися постійною, або знижуватися в залежності від відносної величини цих двох протидіючих чинників.

На рис. 2 наведено залежності між щільністю, швидкістю та інтенсивністю транспортного потоку.

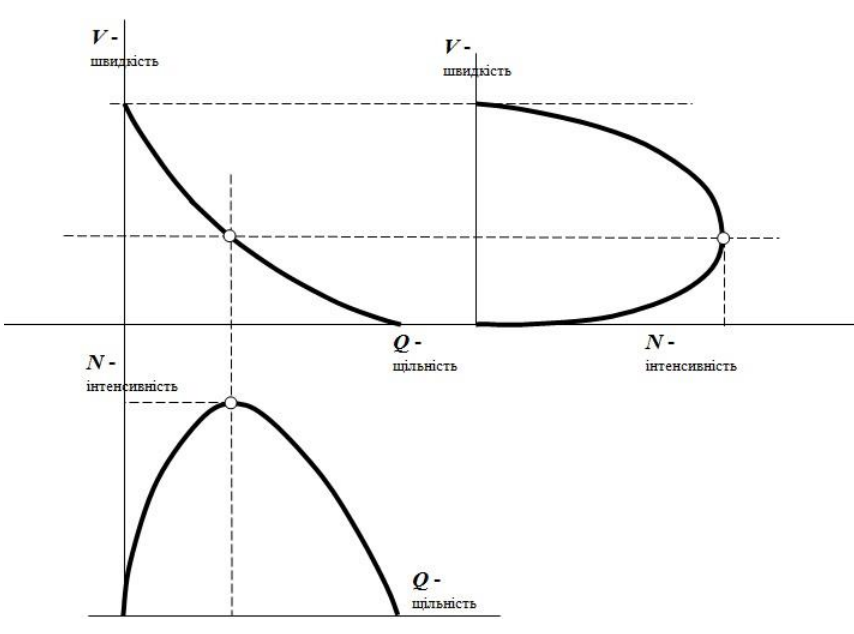

Рисунок 2 - Графічні залежності фундаментальних параметрів ТП
Залежність між швидкістю і щільністю монотонно спадає відповідно до вище наведеної закономірності і в різних наукових джерелах представляється кривою або ж прямою лінією [7]. Залежності між швидкістю та інтенсивністю і між інтенсивністю та щільністю інтерпретуються як параболи, що мають точку перегину для значення максимальної інтенсивності транспортного потоку. Ця точка максимуму інтенсивності відповідає певному значенню швидкості $V$ і щільності $Q$ потоку.

Таким чином, складну залежність інтенсивності транспортного потоку від швидкості та щільності можна представити у наступному вигляді:

$$
N=V(Q) \cdot Q \text {. }
$$

Графічно ця залежність у літературних джерелах зображується у вигляді так званої основної діаграми транспортного потоку (рис. 3) [6]. Ця діаграма будується, виходячи із припущення, що у транспортному потоці всі ТЗ дотримуються безпечного режиму руху. Діаграма відбиває зміну стану однорядного транспортного потоку в залежності від збільшення його інтенсивності і щільності. 


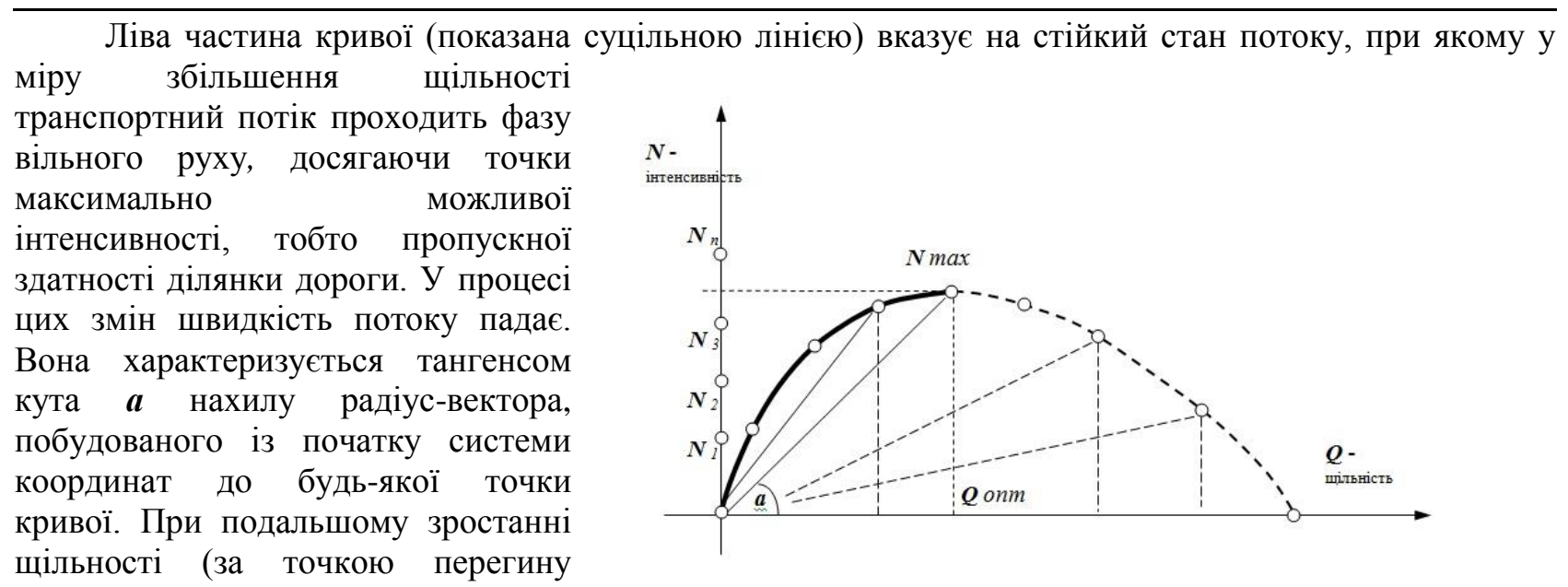
кривої) потік стає зв'язаним і нестійким (ця гілка кривої показана

Рисунок 3 - Основна діаграма транспортного потоку штриховою лінією).

Перехід потоку в нестійкий стан відбувається внаслідок зниження плавності руху, наприклад, при появі перешкоди на ділянці дороги, несприятливих погодних умовах і т. і. «Плаваюча» швидкість лідера групи вимагає гальмування різної інтенсивності для наступних ТЗ, що рухаються у черзі, а потім і їх розгонів, що створює пульсуючий, нестійкий потік.

Подальше зниження інтенсивності потоку до нуля при швидкості теж рівній 0, веде до максимальної щільності потоку ТЗ. Слід зауважити, що якби існувала технічна можливість синхронного руху потоку при максимальній його щільності, то діаграма являла б собою просто вертикальну лінію.

Різке гальмування потоку із-за будь-яких причин викликає так звану «ударну хвилю» транспортного потоку. «Ударна хвиля» $є$ джерелом виникнення ланцюгових зіткнень у напрямі руху, які типові для щільних транспортних потоків. В точках 0 i $Q_{\max }$ інтенсивність руху рівна 0 , тобто на дорозі або немає транспортних засобів, або потік знаходиться у стані затору (нерухомості) [18].

Залежність між інтенсивністю і швидкістю транспортного потоку (рис. 2) дозволяє отримати дуже наближену оцінку умов руху Т3 по транспортній мережі при певному рівні безпеки і 3 певними поєднаннями значень інтенсивності, швидкості і щільності руху. Ця залежність хоча і відіграє важливу роль у теорії транспортних потоків, однак не дає відповіді на безліч конкретних запитань, щодо проведення вимірювань параметрів транспортного потоку, створення математичних моделей його функціонування та шляхів розв’язання проблем, що виникають на конкретних ділянках дорожньої мережі.

В даній макроскопічній моделі залежність щільності від інтенсивності є гладкою неперервною функцією, отже, гранична пропускна спроможність ділянки дороги визначається безпосередньо щільністю потоку. На жаль, це чисто теоретичне допущення, і воно погано описує реальну ситуацію на дорогах, особливо у місті. Наприклад, при практичних замірах основних параметрів транспортного потоку у великих містах фундаментальна діаграма залежності інтенсивності від щільності потоку мала «провал» на певному діапазоні щільності (рис. 4). Така поведінка діаграми пояснювалася переміщенням Т3 із однієї полоси на іншу, що у свою чергу уповільнювало рух всього транспортного потоку, а значить зменшувало інтенсивність руху транспорту.

Взагалі, спроби «підправити» або удосконалити фундаментальну діаграму розпочалися наприкінці 20 століття і тривають досі [15,16,22,23,24]. На наш погляд, основним недоліком робіт науковців, що працюють у галузі функціонування транспортних систем, є намагання уточнити залежності тільки між окремими параметрами моделі руху ТП. «Плоске» представлення основної діаграми транспортного потоку або іi частин, не можливість відслідкувати за діаграмою пікові навантаження на окремі ділянки транспортної мережі, ігнорування інколи суті і часу переходу параметрів моделі транспортного потоку в область комплексних значень - все це не дозволяє ефективно оптимізувати функціонування ТП у місті.

Від так, актуальним залишається завдання удосконалення як методів збору та обробки інформації про транспортні потоки, математичних методів для їх моделювання, так і геометричного, наочного представлення залежностей між базовими параметрами, що описують конкретні транспортні потоки. 
Мета роботи. Проведені дослідження ставили за мету удосконалення математичної моделі функціонування транспортних потоків на перевантажених ділянках міської дорожньої мережі за рахунок багатовимірної інтерпретації залежності між базовими параметрами ТП у різні часові інтервали. Для досягнення поставленої мети вирішувалися наступні задачі:

- проаналізувати залежності між основними параметрами функціонування транспортних потоків на проблемних ділянках дорожньої мережі;

- розробити ефективні алгоритми збору вихідних даних, обробки та розрахунку параметрів для удосконалення руху ТЗ із оптимальними показниками інтенсивності ТП;

- провести комп'ютерну реалізацію розроблених алгоритмів в середовищі Mathcad;

- розробити геометричну модель багатовимірного представлення залежностей між базовими параметрами ТП у різні часові інтервали; мережі.

- розробити методику оптимізації пропускної здатності ТЗ на перевантажених ділянках

Основна частина. Ухвалення рішень щодо організації дорожнього руху і перевезень, плануванню роботи транспортних систем, оцінка ефективності функціонування вулично-дорожньої мережі можливі тільки на основі вивчення параметрів транспортних потоків і залежностей між ними в конкретних умовах. Тому збір i обробка інформації про залежності між основними характеристиками транспортних потоків - інтенсивністю, щільністю і швидкістю - $\epsilon$ істотною частиною діяльності по організації дорожнього руху, особливо в умовах міста $[12,13,14,19]$.

Як показали численні експериментальні дослідження, залежність інтенсивності потоку від щільності автомобілів не $\epsilon$ неперервною кривою, іiі максимум має складну структуру. Він складається із не пов'язаних одна із одною гілок кривої. А окремі зони кривої називають фазами станів транспортного потоку (рис. 5). Існування різних фаз залежності інтенсивності від щільності використовується для класифікації

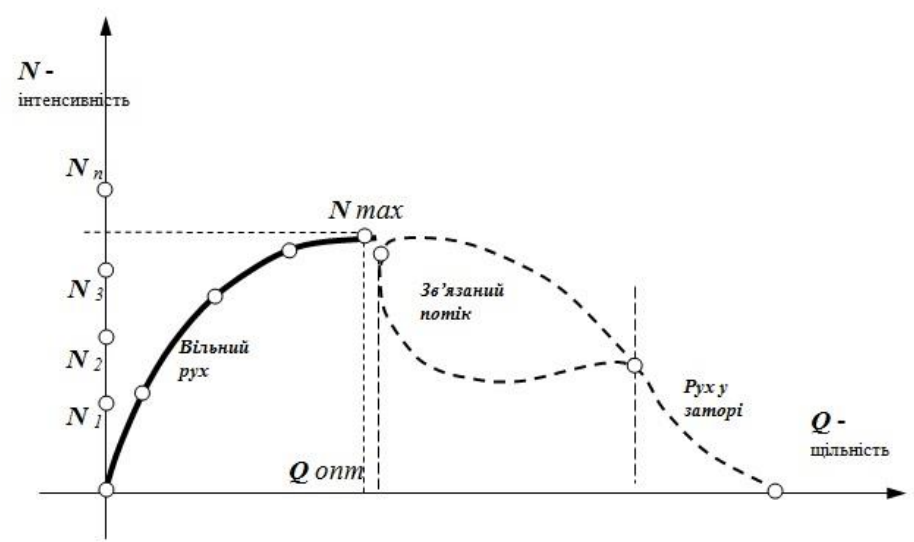

Рисунок 5 - Фазове представлення основної діаграми транспортного потоку певних станів автотранспортних потоків: Зростаюча гілка характеризує вільний рух транспорту, а спадаюча зона кривої - характеризує зв'язаний потік, рух у заторі, аж до повної зупинки руху ТП [17].

Однак і фазове представлення станів транспортного потоку не дає відповіді на запитання про пікові, нестаціонарні його стани у різні часові періоди на дорозі. Тому пропонується для опису трафіку на проблемній ділянці дороги включити до математичної моделі і іiі наочного представлення, крім залежностей між трьома базовими змінними транспортного потоку (тривимірна система координат) - навантаження або інтенсивність потоку, швидкість і щільність, ще і четверту координату, пов’язану із залежністю кожного із базових параметрів від часового інтервалу.

Класично, навантаження і інтенсивність потоку - це два показники для виміру об'єму транспортного потоку, що проходить через фіксоване місце на дорозі в одному напрямі протягом визначеного періоду часу. Відмінність між навантаженням і інтенсивністю потоку дуже важлива. Навантаження - це кількість транспортних засобів, які проходять контрольну точку впродовж певного інтервалу часу. Інтенсивність потоку представляє собою кількість ТЗ, що проходять ту ж точку протягом інтервалу, меншого за 1 годину, поділеного на час спостереження.

Відмінність між поняттями навантаження і інтенсивності потоку можна проілюструвати за допомогою значень навантаження для чотирьох послідовних 15-хвилинних періодів руху. Нехай чотири значення такі: $1300,1700,1200,800$. Загальне годинне навантаження є сума доданків, тобто 5000 транспортних засобів. Інтенсивність потоку, проте, варіюється для кожного 15-хвилинного періоду. Впродовж 15-хвилинного періоду максимального навантаження інтенсивність потоку складає 1700 ТЗ або 6800 авт./год. Зрозуміло, що через досліджувану контрольну точку не проїхало 
6800 транспортних засобів впродовж години спостережень, хоча потік мав таку інтенсивність протягом одного із контрольних 15 -хвилинних проміжків часу.

Саме врахування пікових значень інтенсивності потоку важливе в процесі аналізу пропускної здатності. Якщо, наприклад, пропускна здатність ділянки дороги, що аналізується, складає 5000 авт./год, впродовж пікового 15-хвилинного періоду цей показник допускає перевищення, коли той же потік має інтенсивність в 6800 авт./год. Це може стати серйозною проблемою, оскільки утвориться затор, а процес ліквідації затору, що виник із-за перевищення пропускної здатності, може розтягнутися на невизначений час. Тому пікові значення інтенсивності транспортного потоку вкрай важливі для прийняття рішень по організації дорожнього руху.

Серед трьох базових параметрів транспортного потоку найбільш просто вимірювати показники інтенсивності руху Т3, що змінюються у часовому інтервалі, наприклад за добу $N(T)$. Тому, на явно перевантаженій ділянці дороги типу «пляшкового горла» у м. Луцьку, були у різні часові інтервали зняті показники інтенсивності руху ТЗ. Для прийняття більш зрозумілих і ефективних управлінських рішень за результатами моделювання, транспортний потік розділявся за категоріями Т3, які найхарактерніші для даної ділянки: тролейбуси, маршрутні автобуси, вантажні автомобілі, легкові автомобілі, інше. Результати залежності інтенсивності руху Т3 від часу доби, для прикладу, наведено на рис. 6.

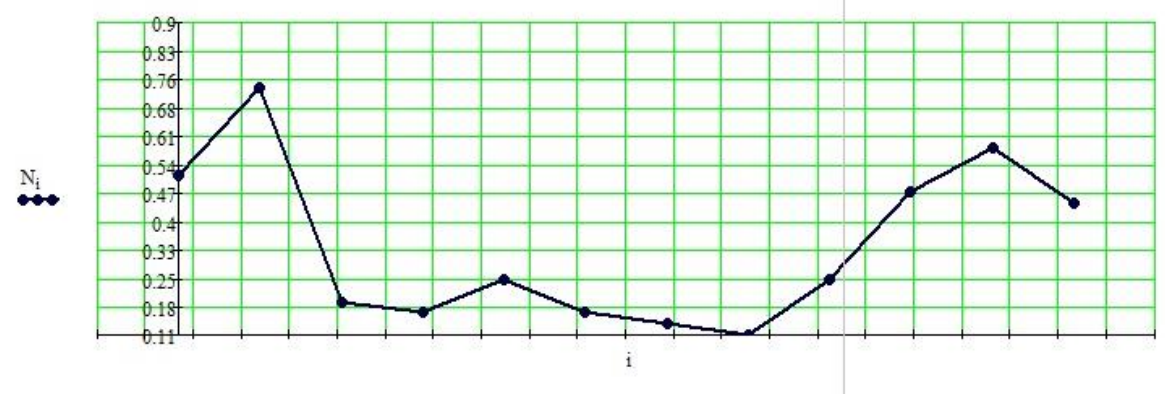

Рисунок 6 - Графік інтенсивності ТП у часовому інтервалі

Хоча графік інтенсивності транспортного потоку забезпечує спосіб числового представлення значень пропускної здатності, швидкість (чи час проїзду, що відповідає їй) є важливою мірою якості обслуговування трафіку. Це суттєвий критерій ефективності, що визначає рівні обслуговування для дорожніх ділянок практично усіх типів.

У контексті цієї роботи використовується середня швидкість проїзду у часі транспортних засобів різного типу і визначається вона, виходячи із показників інтенсивності транспортного потоку. За основу була прийнята відома модель Танака залежності $V(Q)$, хоча з таким же успіхом можна скористатися будь-якою іншою моделлю макроскопічної групи. У даній моделі щільність транспортних засобів на ділянці розраховується виходячи із безпечної відстані між транспортними засобами при русі на досліджуваній ділянці із певною швидкістю.

$$
Q(V)=\frac{1}{d(V)},
$$

де - $d(V)=c_{1} V^{2}+c_{2} V+L-($ м) безпечна відстань між транспортними засобами у потоці;

$V-\left(\frac{M}{c}\right)$ - середня швидкість руху потоку;

$L-(\mathcal{M})$ - максимальна довжина Т3;

$c_{1}-\left(\frac{c^{2}}{M}\right)$ - коефіцієнт пропорційності гальмівного шляху;

$c_{2}-(c)$ - час, що характеризує реакцію водія.

Коефіцієнт $c_{1}$ приймається за наступною класифікацією:

для нормальної дороги: $c_{1}=0.0285$;

для мокрої дороги $c_{1}=0.0570$;

для дороги з ожеледицею $c_{1}=0.1650$. 
Коефіцієнт $c_{2}=0.504$.

Враховуючи основний вираз для транспортного потоку (1) можна залежність інтенсивності від швидкості подати у вигляді:

$$
N(V)=\frac{V}{c_{1} V^{2}+c_{2} V+L}
$$

Спробуємо знайти залежність $V(N)$.

$$
V=d(V) \cdot N \quad \text { або } \quad c_{1} \cdot V^{2} \cdot N+\left(c_{2} \cdot N-1\right) \cdot V+L \cdot N=0 .
$$

Провівши низку перетворень отримаємо:

$$
V(N)=\frac{\left(1-c_{2} \bullet N\right) \pm \sqrt{D}}{2 c_{1} \bullet N},
$$

де - дискримінант $D=\left(c_{2} \cdot N-1\right)^{2}-4 \cdot c_{1} \cdot L \cdot N^{2}$.

Для перевірки запропонованого алгоритму знаходження середньої швидкості через параметри інтенсивності була створена програма, результати роботи якої наведені на рис.7. Видно, що на деяких часових інтервалах через пікову інтенсивність параметри швидкості переходять на множину комплексних значень, що не прийнятно для досліджень транспортних потоків.
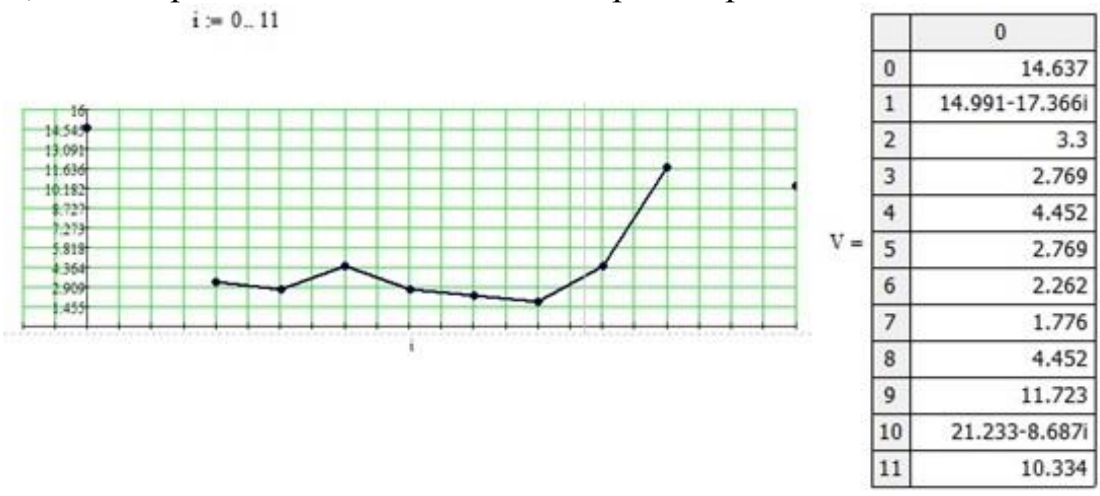

Рисунок 7 - Графік середньої швидкості за показниками інтенсивності ТП у часовому інтервалі

Причина - дискримінант у виразі (5) від’ємний. Для того, щоб визначити максимально допустимі межі інтенсивності транспортного потоку на ділянці прирівняємо дискримінант до 0 i визначимо критичні значення інтенсивності:

$$
\begin{aligned}
& \left(c_{2} \cdot N-1\right)^{2}-4 \cdot c_{1} \cdot L \cdot N^{2}=0, \\
& N=\frac{c_{2} \pm 2 \sqrt{L \cdot c_{1}}}{c_{2}^{2}-4 L \cdot c_{1}} .
\end{aligned}
$$

Тобто, значення інтенсивності руху транспортних засобів не може перевищувати:

$$
N \leq \frac{c_{2} \pm 2 \sqrt{L \cdot c_{1}}}{c_{2}{ }^{2}-4 L \cdot c_{1}}
$$




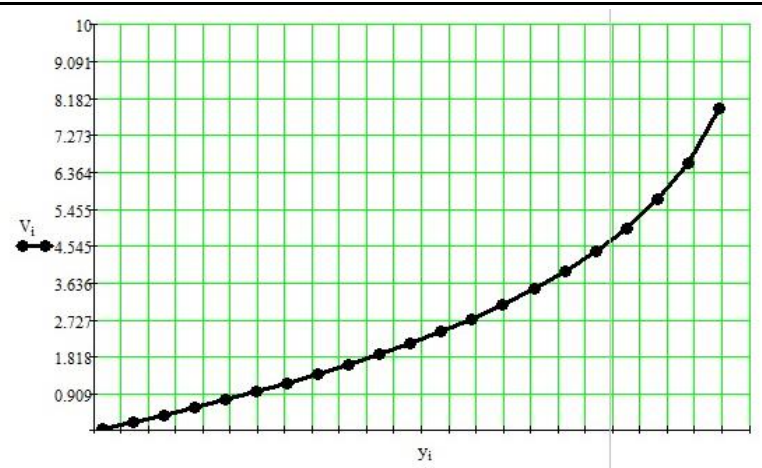

Рисунок 8 - Графік залежності швидкості від інтенсивності ТП у зоні вільного руху

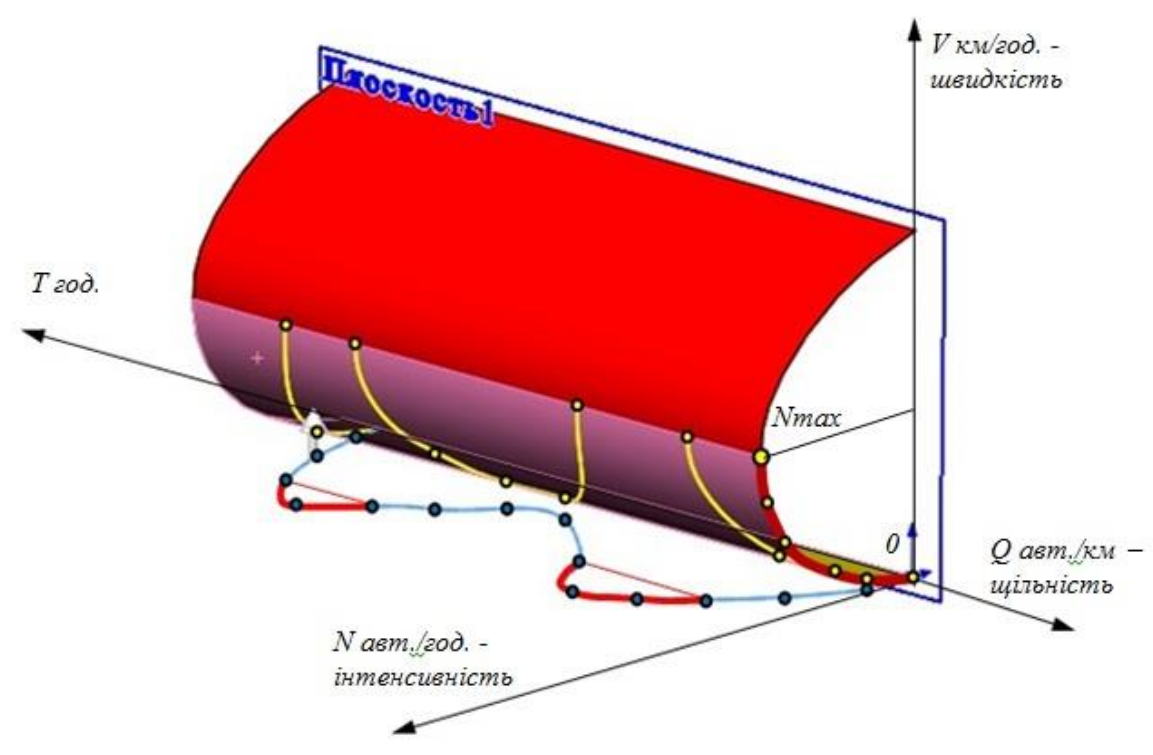

Рисунок 9 - Модель обрізання пікових показників інтенсивності ТП на певних часових інтервалах

Спираючись на результати роботи [11] та дані графіка (рис. 8), будуємо просторову модель залежності швидкості, інтенсивності та часового інтервалу. Вона представляє собою циліндричну поверхню у тривимірній системі координат, із максимально можливою безпечною інтенсивністю транспортного потоку на ділянці у досліджувані часові інтервали. Поверхня описується рівнянням:

$$
F_{1}(N, V)=0
$$

із направляючою $V=f(N)$.

Друга циліндрична поверхня $F_{2}(N, T)=0$ побудована із твірною, паралельною осі $V$ i направляючою у вигляді залежності інтенсивності ТП від часу. Лінія перетину таки двох поверхонь, у загальному випадку, $є$ просторовою неперервною кривою виду:

$$
\left\{\begin{array}{l}
F_{1}(N, V)=0, \\
F_{2}(N, T)=0 .
\end{array}\right.
$$

Однак, як видно із рис. 9, вона може геометрично представляти собою множину окремих сегментів, що мають розриви на твірній $N_{\text {max }}$ у певні часові інтервали. Така модель надає важливу інформацію для оптимізації ТП, а саме - у які проміжки часу слід розріджувати транспортний потік на заданій ділянці дороги.

За таким же принципом будуються і інші складові багатовимірної діаграми транспортного потоку (рис. 10). Наприклад, третій параметр характеристики ТП - щільність потоку $Q$. Даний параметр визначає кількість автомобілів, що займають задану довжину ділянки дороги у певний момент часу.

Слід зауважити, що безпосереднє вимірювання параметра щільності на практиці доволі проблематичне і вимагає наявності вигідної точки для фотографування або спостереження значної 
ділянки дорожньої магістралі. У контексті даних досліджень щільність (авт./км) визначається у розрахункові інтервали часу в залежності від інтенсивності та швидкості ТП у ці ж часові інтервали за виразом (1).

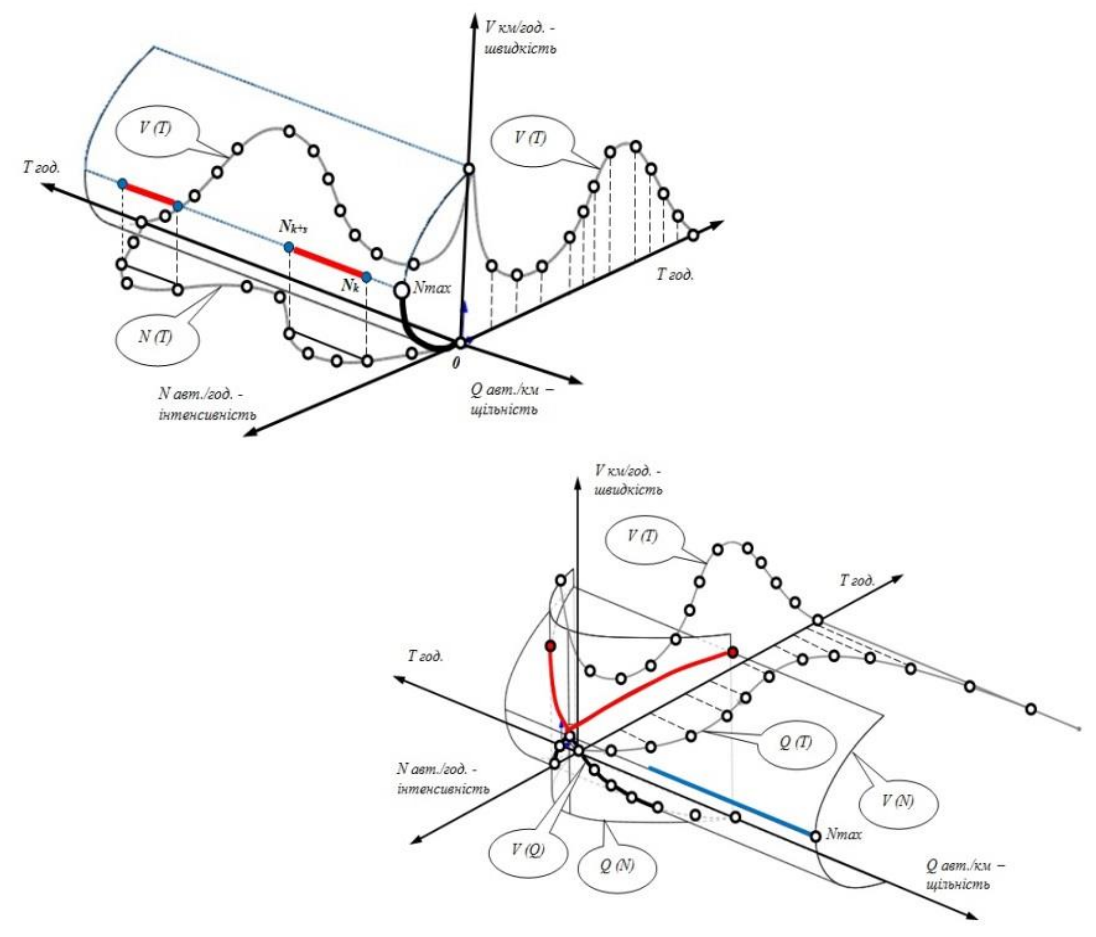

Рисунок 10 - Багатовимірна модель основної діаграми ТП

На рис. 10 показана щільність ТП у досліджувані інтервали часу, за якими побудована залежність щільності від інтенсивності $Q(N)$. Ця залежність є направляючою циліндричної поверхні $F_{3}(Q, N)=0$, яка наочно показує якість обслуговування трафіку на ділянці. Система рівнянь

$$
\left\{\begin{array}{l}
F_{1}(N, V)=0, \\
F_{3}(Q, N)=0
\end{array}\right.
$$

задає лінію перетину двох циліндричних поверхонь, яка показує залежність швидкості від щільності та інтенсивності, тобто описує показник свободи маневру будь-якого ТЗ у транспортному потоці.

Запропонована багатовимірна просторова модель демонструє узагальнене представлення всіх основних співвідношень, що $є$ основою для аналізу пропускної здатності дорожніх ділянок із безперервним потоком.

Форма направляючих кривих циліндричних поверхонь $F_{1}, F_{3}$ залежать від домінуючих умов трафіку і дороги на досліджуваній ділянці. Хоча дані направляючі криві у запропонованій моделі неперервні, визначальними для характеристик ТП є криві перетину циліндричних поверхонь, які можуть зазнавати розривів, що $\mathrm{i}$ підтверджується численними проведеними практичними дослідженнями проблемних ділянок доріг міста Луцька.

Але запропонована модель (рис. 10) ілюструє і ряд класичних, важливих положень. Перше: нульова інтенсивність транспортного потоку на ділянці дороги виникає за двох різних умов. Нульовий показник має місце тоді, коли транспорт відсутній на ділянці дороги - щільність ТП дорівнює нулю і інтенсивність потоку також виявляється нульовою. Швидкість ТЗ для такої умови носить чисто теоретичний характер. 3 іншого боку нульова умова відповідає ситуації, коли щільність стає такою високою, що усі ТЗ вимушені повністю зупинитися - швидкість дорівнює нулю $\mathrm{i}$ інтенсивність також дорівнює нулю, оскільки рух відсутній.

У міру зростання інтенсивності потоку від нуля щільність також зростає, оскільки на дорозі 3'являється більше число ТЗ. При цьому із-за взаємного впливу окремих Т3 їх швидкість падає. При зростанні щільності, як показує узагальнена модель (рис. 10), швидкість на верхній частині 
циліндричної поверхні $F_{1}$ зменшується (червона крива на циліндрі), перш, ніж буде досягнутий рівень пропускної здатності (зв'язаний потік), а на нижній (вільний рух) - зростає. Швидкість нижньої частини циліндричної поверхні прагне до забезпечення максимальної інтенсивності потоку і $\epsilon, ~ з$ будь-яких позицій, оптимальною.

Висновки. У даній роботі, на основі аналізу залежностей між основними характеристиками функціонування транспортних потоків на перевантажених ділянках дорожньої мережі, запропоновано ефективні підходи до збору вихідних даних, їх обробки та розроблені алгоритми розрахунку параметрів для удосконалення руху ТЗ із оптимальними показниками інтенсивності ТП. Проведена комп'ютерна реалізація запропонованих алгоритмів в середовищі Mathcad 15. Розроблена геометрична модель багатовимірного представлення залежностей між основними параметрами ТП у різні часові інтервали, яка дозволяє ефективно розріджувати щільність руху транспортних засобів у пікові періоди. Така наочна інтерпретація основної діаграми транспортного потоку дає можливість швидко і якісно аналізувати стан пропускної здатності Т3 на проблемних ділянках і ефективно приймати управлінські рішення щодо удосконалення трафіку.

1. Бирюков В. В. Влияние доступности на эффективность транспортных систем [Текст] /В.В. Бирюков, К.Э. Сафронов // Вестник СибАДИ. - 2010. - № 2 (16). - С. 71-77.

2. Бунеев В. М. Эффективность городского пассажирского транспорта: методы оценки и обоснования [Текст] / В.М. Бунеев// - Новосибирск: НГАВТ, 2008. - 401 с.

3. Вельможин А. В. Основы теории транспортных процессов и систем: учебное пособие [Текст] / А. В. Вельможин, В. А. Гудков, Л. Б. Миротин// - Москва: Академия, 2015. - 221с.

4. Гасников А. В. Введение в математическое моделирование транспортных потоков: учебное пособие [Текст] / А. В. Гасников [и др.]; ред. А. В. Гасников.// - 2-е изд., испр. и доп. - Москва: МЦНМО, 2013. - 426 с.

5. Герами В. Д. Управление транспортными системами. Транспортное обеспечение логистики: учебник [Текст] /В.Д. Герами, А.В. Колик// - М., 2015. - 512 с.

6. Горев А. Э. Информационные технологии на транспорте: учебник [Текст] / А. Э. Горев // - Москва: Юрайт, 2016. - 272 с.

7. Горев А. Э. Основы теории транспортных систем: учеб. пособие [Текст] / А. Э. Горев// - СПб. : СПбГАСУ, 2010. -214 с.

8. Захаров Н. С. Закономерности формирования количества легковых автомобилей на улично-дорожной сети города [Текст] / Н. С. Захаров, Е. Ф. Бояркина // - Тюмень: ТюмГНГУ, 2011. - 160 с.

9. Михайлов А. Ю. Транспортное моделирование: от города к агломерации [Текст] / А.Ю. Михайлов, Е.С. Преловская // Известия Волгоградского государственного технического университета. - 2014.- №3.- С. 64-66.

10. Персианов, В.А. Моделирование транспортных систем [Текст] / В.А. Персианов, К.Ю. Скалов, Н.С. Усков // - М. : Транспорт, 1972. - 208 с.

11. Пустюльга С. І. Дискретне визначення геометричних об’єктів числовими послідовностями [Текст]: дис. докт. техн. наук. / С. І. Пустюльга - К., 2006. -320с.

12. Пустюльга С. I. Систематизована формалізація вхідних даних роботи маршрутних автобусів для оптимізації міських пасажирських перевезень [Текст] /C. I. Пустюльга, I.С. Мурований // Науковий журнал “Сучасні технології в машинобудуванні та транспорті" - Луцьк: Луцький НТУ, 2014. - Вип. 1. - С. 102-108.

13. Пустюльга С. И. Систематизация исходных данных для построения имитационной модели работы маршрутных такси [ТЕКСТ] /С. И. Пустюльга, И.С. Мурованый // XXI Научно-техническая конференция с международным участием “транспорт, екология - устойчивое развитие” ЕКО ВАРНА, 14-16.05.2015, - С. 255-261.

14. Пустюльга С. Впровадження інтелектуальних технічних систем на пасажирському транспорті м. Луцька [Текст] /С. Пустюльга, I. Мурований, С. Чухрій // Всеукраїнська науково-технічна конференція "Проблеми 3 транспортними потоками і напрями їх розв'язання”, Львів 2015, - С. 67-69.

15. Сафронов К. Э. Совершенствование методов управления развитием транспортных систем крупных городов [Текст] /К. Э. Сафронов, Э. А. Сафронов // Вестник СибАДИ. - 2009. - №3 (13).- С. $24-28$.

16. Сафронов К. Э. Инновационные методы повышения эффективности транспортных систем городов [Текст] /К.Э. Сафронов, Э.А. Сафронов // Вестник Московского автомобильно-дорожного государственного технического университета. - М.: МАДИ, 2011. - №3 (26). - С. 7-12.

17. Сафронов Э. А. Модернизация маршрутных сетей больших городов [Текст] /Э.А. Сафронов, К.Э. Сафронов // Социально-экономические проблемы развития и функционирования транспортных систем городов и зон их влияния: материалы XXI Международной науч.-практ. конф. - Екатеринбург: АНМБ, 2015. - С. 189-194.

18. Сафронов Э. А. Пути решения транспортных проблем в городах [Текст] /Э.А. Сафронов, К.Э. Сафронов, Е.С. Семенова // Развитие теории и практики автомобильных перевозок, транспортной логистики: сборник научных трудов кафедры «Организация перевозок и управление на транспорте» в рамках Международной научно-практической конференции. - Омск: СибАДИ, 2016. - С. 284-291.

19. Спирин И. В. Организация и управление пассажирскими автомобильными перевозками: учебник [Текст] /И.В. Спирин// - 5-е изд., перераб. - М. : Издательский центр "Академия", 2010. - 400 с.

20. Okun Arthur M. Prices and Quantities: A Macroeconomic Analysis / Arthur M. Okun. - Washington, DC: Brookings Institution, 1981. -367 p.

21. Reedy J. Marketing to consumers with disabilities how to identify and meet the growing market needs of 43 million Americans. Probus Publishing Company, Chicago / J. Reedy // Tourism and Hospitality Research September. - 2007. - № 7. - P. 212-229. 
22. Ringaert L. Is Your Business Open to All? (Ten Point Checklist) / L. Ringaert, B. Knutson, D. Rapson // Universal Design Institute, Faculty of Architecture. - University of Manitoba. - 2001.

23. Ringaert L. Para Consulting / L. Ringaert, O Krassioukova, D. Enns // Maximizing Abilities in the Workplace. Funded by the Workers Compensation Board of Manitoba, Canada. - 2005.

24. Safronov K. Transport for people with disabilities / K. Safronov // Proceedings "Technics. Technologies": XVI International Scientific-Technical Conference trans \& MOTAUTO '09. Sea resort Sunny Beach-Bulgaria. September, 17th- 19th. 2009. - P. 129-132.

\section{REFERENCES}

1. Biryukov V. V. Vliyanie dostupnosti na effektivnost transportnyih sistem [Tekst] / V.V. Biryukov, K.E. Safronov // Vestnik SibADI. - 2010. - \# 2 (16). - S. 71-77.

2. Buneev V. M. Effektivnost gorodskogo passazhirskogo transporta: metodyi otsenki i obosnovaniya [Tekst] / V.M. Buneev// - Novosibirsk: NGAVT, 2008. - $401 \mathrm{~s}$.

3. Velmozhin A. V. Osnovyi teorii transportnyih protsessov i sistem: uchebnoe posobie [Tekst] / A. V. Velmozhin, V. A. Gudkov, L. B. Mirotin// - Moskva: Akademiya, 2015. - 221s.

4. Gasnikov A. V. Vvedenie v matematicheskoe modelirovanie transportnyih potokov: uchebnoe posobie [Tekst] / A. V. Gasnikov [i dr.]; red. A. V. Gasnikov.// - 2-e izd., ispr. i dop. - Moskva: MTsNMO, 2013. - 426 s.

5. Gerami V. D. Upravlenie transportnyimi sistemami. Transportnoe obespechenie logistiki: uchebnik [Tekst] /V.D. Gerami, A.V. Kolik// - M., 2015. - 512 s.

$272 \mathrm{~s}$.

6. Gorev A. E. Informatsionnyie tehnologii na transporte: uchebnik [Tekst] / A. E. Gorev // - Moskva: Yurayt, 2016. -

214 s.

7. Gorev A. E. Osnovyi teorii transportnyih sistem: ucheb. posobie [Tekst] / A. E. Gorev// - SPb. : SPbGASU, 2010. -

8. Zaharov N. S. Zakonomernosti formirovaniya kolichestva legkovyih avtomobiley na ulichno-dorozhnoy seti goroda [Tekst] / N. S. Zaharov, E. F. Boyarkina // - Tyumen: TyumGNGU, 2011. - $160 \mathrm{~s}$.

9. Mihaylov A.Yu. Transportnoe modelirovanie: ot goroda k aglomeratsii [Tekst] / A.Yu. Mihaylov, E.S. Prelovskaya // Izvestiya Volgogradskogo gosudarstvennogo tehnicheskogo universiteta. - 2014.- \#3.- S. 64-66.

10. Persianov V. A. Modelirovanie transportnyih sistem [Tekst] / V.A. Persianov, K.Yu. Skalov, N.S. Uskov // - M. : Transport, 1972. - $208 \mathrm{~s}$.

11. Pustyulga S. I. Diskretne viznachennya geometrichnih ob'EktIv chislovimi poslIdovnostyami [Tekst]: dis. dokt. tehn. nauk. / S. I. Pustyulga - K., 2006. - 320s.

12. Pustyulga S. I. Sistematizovana formalIzatsIya vhIdnih danih roboti marshrutnih avtobusIv dlya optimIzatsIYi mIskih pasazhirskih perevezen [Tekst] / S. I. Pustyulga, I.S. Murovaniy // Naukoviy zhurnal "SuchasnI tehnologIYi v mashinobuduvannI ta transportl" - Lutsk: Lutskiy NTU, 2014. - Vip. 1. - S. 102-108.

13. Pustyulga S. I. Sistematizatsiya ishodnyih dannyih dlya postroeniya imitatsionnoy modeli rabotyi marshrutnyih taksi [Tekst] /S. I. Pustyulga, I.S. Murovanyiy // XXI nauchno-tehnicheskaya konferentsiya s mezhdunarodnyim uchastiem "Transport, ekologiya - ustoychivoe razvitie" EKO Varna, 14-16.05.2015, - S. 255-261.

14. Pustyulga S. Vprovadzhennya Intelektualnih tehnIchnih sistem na pasazhirskomu transportI m. Lutska [Tekst] / S. Pustyulga, I. Murovaniy, S. Chuhrly // VseukraYinska naukovo-tehnIchna konferentsIya "Problemi z transportnimi potokami I napryami Yih rozv'yazannya”, LvIv 2015, - S. 67-69.

15. Safronov K.E. Sovershenstvovanie metodov upravleniya razvitiem transportnyih sistem krupnyih gorodov [Tekst] / K.E. Safronov, E.A. Safronov // Vestnik SibADI. - 2009. - \#3 (13).- S. 24-28.

16. Safronov K. E. Innovatsionnyie metodyi povyisheniya effektivnosti transportnyih sistem gorodov [Tekst] /K.E. Safronov, E.A. Safronov // Vestnik Moskovskogo avtomobilno-dorozhnogo gosudarstvennogo tehnicheskogo universiteta. - M.: MADI, 2011. - \#3 (26). - S. 7-12.

17. Safronov E. A. Modernizatsiya marshrutnyih setey bolshih gorodov [Tekst] / E.A. Safronov, K.E. Safronov // Sotsialno-ekonomicheskie problemyi razvitiya i funktsionirovaniya transportnyih sistem gorodov i zon ih vliyaniya: materialyi XXI Mezhdunarodnoy nauch.-prakt. konf. - Ekaterinburg: ANMB, 2015. - C. 189-194.

18. Safronov E. A. Puti resheniya transportnyih problem v gorodah [Tekst] / E.A. Safronov, K.E. Safronov, E.S. Semenova // Razvitie teorii i praktiki avtomobilnyih perevozok, transportnoy logistiki: sbornik nauchnyih trudov kafedryi «Organizatsiya perevozok i upravlenie na transporte» v ramkah Mezhdunarodnoy nauchno-prakticheskoy konferentsii. - Omsk: SibADI, 2016. - C. 284-291.

19. Spirin I. V. Organizatsiya i upravlenie passazhirskimi avtomobilnyimi perevozkami: uchebnik [Tekst] / I.V. Spirin// 5-e izd., pererab. - M. : Izdatelskiy tsentr "Akademiya", 2010. - 400 s.

20. Okun Arthur M. Prices and Quantities: A Macroeconomic Analysis / Arthur M. Okun. - Washington, DC: Brookings Institution, 1981. - 367 p.

21. Reedy J. Marketing to consumers with disabilities how to identify and meet the growing market needs of 43 million Americans. Probus Publishing Company, Chicago / J. Reedy // Tourism and Hospitality Research September. - 2007. - № 7. - P. 212-229.

22. Ringaert L. Is Your Business Open to All? (Ten Point Checklist) / L. Ringaert, B. Knutson, D. Rapson // Universal Design Institute, Faculty of Architecture. - University of Manitoba. - 2001.

23. Ringaert L. Para Consulting / L. Ringaert, O Krassioukova, D. Enns // Maximizing Abilities in the Workplace. Funded by the Workers Compensation Board of Manitoba, Canada. - 2005.

24. Safronov K. Transport for people with disabilities / K. Safronov // Proceedings "Technics. Technologies": XVI International Scientific-Technical Conference trans \& MOTAUTO '09. Sea resort Sunny Beach-Bulgaria. September, 17th- 19th. 2009. - P. 129-132. 
Пустюльга С. И., Придюк В.М., Самостян В.Р. Многомерная геометрическая модель функционирования транспортного потока на перегруженном участке дорожной сети.

В работе предложены эффективная методика сбора исходных данных, способы обработки и алгоритмы расчета эксплуатационных параметров транспортного потока для усовершенствования движения ТС с оптимальными показателями интенсивности и скорости на перегруженных участках дорожной сети. Проведена компьютерная реализация предложенных алгоритмов в среде Mathcad 15. Разработана геометрическая модель многомерного представления зависимостей между основными базовыми характеристиками транспортного потока в разные временные интервалы, которая позволяет эффективно разжижать плотность движения ТС в пиковые периоды. Предложена многомерная интерпретация основной диаграммы транспортного потока, которая дает возможность быстро и качественно анализировать состояние пропускной способности ТС на отдельных участках дороги и эффективно принимать управленческие решения по совершенствованию трафика.

Ключевые слова: интенсивность транспортного потока, транспортное средство, основная диаграмма ТП, плотность движения ТС, многомерное представление диаграммы ТП.

S. Pustiulha, V. Prydiuk, V. Samostian. A multidimensional geometric model of the functioning of the transport stream on a section of the road network.

The paper proposes an effective method for collecting baseline data, processing methods and algorithms for calculating the operational parameters of a traffic flow to improve vehicle traffic with optimal indicators of intensity and speed on congested sections of the road network. A computer implementation of the proposed algorithms in the Mathcad 15 environment has been carried out. A geometric model of the multidimensional representation of dependencies between the basic characteristics of a traffic flow in different time intervals has been developed, which makes it possible to effectively dilute the vehicle's traffic density during peak periods. A multidimensional interpretation of the main traffic flow diagram is proposed, which makes it possible to quickly and accurately analyze the condition of the vehicle's carrying capacity on certain sections of the road and effectively make management decisions to improve traffic.

Key words: traffic flow intensity, vehicle, main TP diagram, traffic density of the vehicle, multidimensional representation of the TP diagram.

АВТОРИ:

ПУСТЮЛЬГА Сергій Іванович, доктор технічних наук, професор кафедри інженерної та комп'ютерної графіки, Луцький національний технічний університет e-mail: mbf.declutsk@gmail.com.

ПРИДЮК Валентин Михайлович, кандидат технічних наук, доцент кафедри автомобілів і транспортних технологій, Луцький національний технічний університет e-mail: pred_mbf@gmail.com.

САМОСТЯН Віктор Русланович, кандидат технічних наук, доцент кафедри інженерної та комп’ютерної графіки, Луцький національний технічний університет e-mail: cvmbf@ukr.net.

АВТОРЫ:

ПУСТЮЛЬГА Сергей Иванович, доктор технических наук, профессор кафедры инженерной и компьютерной графики, Луцкий национальный технический университет e-mail: mbf.declutsk@gmail.com.

ПРИДЮК Валентин Михайлович, кандидат технических наук, доцент кафедры автомобилей и транспортных технологий, Луцкий национальный технический университет e-mail: pred_mbf@gmail.com.

САМОСТЯН Виктор Русланович, кандидат технических наук, доцент кафедры инженерной и компьютерной графики, Луцкий национальный технический университет e-mail: cvmbf@ukr.net.

AUTHORS:

Serhii PUSTIULHA, Doctor of Technical Sciences, Professor of Engineering and Computer Graphics department, Dean of MBF, Lutsk National Technical University e-mail: mbf.declutsk@ gmail.com.

Valentyn PRYDIUK, PhD in Engeneering, Associate Professor of Automobiles and Transport Technologies department, Lutsk National Technical University e-mail: pred_mbf@gmail.com.

Viktor SAMOSTIAN, PhD in Engeneering, Associate Professor of Engineering and Computer Graphics department, Lutsk National Technical University e-mail: cvmbf@ukr.net. 